\title{
Influential Factors for Sustainable Intention to Visit a National Park during COVID-19: The Extended Theory of Planned Behavior with Perception of Risk and Coping Behavior
}

\author{
Bo-Hyun Seong ${ }^{1}$, Youngseok Choi ${ }^{2}$ and Hyojin Kim ${ }^{3, *}$ \\ 1 Department of Co-Prosperity Research, Chungbuk Research Institute, Cheongju 28517, Korea; sbh@cri.re.kr \\ 2 Department of Strategic Planning, Incheon Tourism Organization, Gaetbeol-ro 12, Yeonsu-gu, \\ Incheon 21999, Korea; creatourism@naver.com \\ 3 Department of Tourism Management, Mokpo National University, Yeongsan-ro 1666, Cheonggye-myeon, \\ Muan-gun 58554, Korea \\ * Correspondence: hyojin1126@hotmail.com
}

check for updates

Citation: Seong, B.-H.; Choi, Y.; Kim, H. Influential Factors for Sustainable Intention to Visit a National Park during COVID-19: The Extended Theory of Planned Behavior with Perception of Risk and Coping Behavior. Int. J. Environ. Res. Public Health 2021, 18, 12968. https:/ doi.org/10.3390/ijerph182412968

Academic Editor: Heesup Han

Received: 20 September 2021 Accepted: 29 November 2021 Published: 8 December 2021

Publisher's Note: MDPI stays neutral with regard to jurisdictional claims in published maps and institutional affiliations.

Copyright: (C) 2021 by the authors Licensee MDPI, Basel, Switzerland. This article is an open access article distributed under the terms and conditions of the Creative Commons Attribution (CC BY) license (https:/ / creativecommons.org/licenses/by/ $4.0 /)$.

\begin{abstract}
Despite the danger of the spread of the COVID-19 pandemic, visits to natural tourism destinations such as national parks are continuing, though people are using less congested trails or minimizing personal contact. Given the danger from COVID-19, the purpose of our study was to use an expanded theory of planned behavior to analyze whether tourists intend to continue to visit national parks. Another purpose for our study was to compare an extant research model based on the theory of planned behavior with the extended model we developed. Frequency analysis, confirmatory factor analysis, structural equation modeling, and other statistical techniques, such as correlation analysis, parsimonious fit index, and squared multiple correlations were employed according to the appropriate objectives. Additionally, the number of 351 participants joined the survey. Our study found that perception of risk of COVID-19 negatively affected attitude and perceived behavioral control in both models. Moreover, the perceived behavioral control had a positive effect on coping behavior. Given the analytical results, our study presents not only theoretical implications for understanding the behavior of those who visit national parks, but also practical implications for operation and management of national parks during the COVID-19 pandemic.
\end{abstract}

Keywords: COVID-19; perception of risk; coping behavior; extended theory of planned behavior; sustainable intention

\section{Introduction}

The global shock from the COVID-19 pandemic has continued. In the past, people have generally recovered from either large or small infectious disease pandemics within about five months, but there is a difference between the past and the present, in that it is difficult to guarantee a complete end to COVID-19 during 2021 [1,2]. For tourism, this uncertainty is having an unprecedented impact on both the inbound and the outbound tourism markets [3,4]. Although the international tourism market continues to stagnate, it is noteworthy that the domestic tourism demand is robustly recovering in several countries [5]. People's desire for tourism can quickly overcome considerable difficulties because of resilience, which is the strength of the mind after a major crisis, even if it is under unexpected cases, such as a pandemic or terrorism [6,7]. Indeed, in Korea there has been a clear increase in visitors around cities among environment-friendly destinations, such as national parks, where movement is easy and safe, depending on the intensity of COVID-19 countermeasures. The social concern driven by the pandemic can emerge as avoidance of travel, but at present our study is still significant, because natural or environmental destinations are being visited consistently and steadily $[8,9]$.

In addition, if advice from experts that the cycle of the pandemic can be shortened is considered, participation in outdoor recreation to meet the desire for travel is likely to 
continue. Additionally, for effective management of areas for outdoor recreation, such as national parks, a fundamental discussion of the psychological factors leading to visiting parks is required. The theory of planned behavior is among the most frequently used theories in relation to intentions to visit national parks [10-12]. Plus, the usefulness of a theory of planned behavior as a theoretical framework for explaining various human behaviors, including tourism, is well-known in academia [13-17]. Constructs of the theory of planned behavior that involve attitude, subjective norms, and perceived behavioral intentions have already identified their significant relations to behavioral intentions by tourists in diverse research [18-21]. According to Ajzen (1991) [22], attitude is defined to be a positive or negative evaluation of specific conduct determined by an individual. Subjective norms indicate positive or negative opinions about specific conduct that a particular group around an individual exhibits. Perceived behavioral control accounts for the perceived level of ease or difficultly a specific action presents to an individual [23]. As an additional example to investigate human behavior, a study on whether constructs of the theory of planned behavior significantly influence behavioral intention in the setting of a national park is essential. In recent years, a wide array of studies have attempted to expand the theory of planned behavior by adding new factors to the variables in the theory, such as attitude, subjective norms, and perceived behavioral control, and to increase its power to explain tourist behavior, thereby contributing to better understanding of the additional influential factors [23]. New study on applications of the extended theory of planned behavior should attempt to explain the complicated behavior of humans in relation to the unpredicted COVID-19 pandemic [13,16,17,24,25].

Due to the outbreak of the COVID-19 pandemic, it is questionable whether tourists visit national parks that are at risk as they would otherwise plan to. Both this question and the rest of our study can be related to protection motivation theory, which deals with cognitive responses such as threat appraisal and coping approval derived from fear appeals [26-28]. Apart from protection motivation theory, our study used the expanded theory of planned behavior to inquire whether tourists intend to continue to visit a national park if they minimize their risk by means of countermeasures, such as using less crowded national trails and having less personal contact. Our study used data about visits to natural destinations such as national parks under the perception of the danger from COVID-19. Extant studies have found that the higher the risk perceived by tourists, the more they switch to other destinations or reduce their risk at the given tourism destination $[23,29]$. Our finding suggests other variables that involve perception of risk and coping behavior regarding COVID-19 that can be added to extend the theory of planned behavior [30,31]. As an additional purpose for our study, we compared the simple research model using the theory of planned behavior with the extended research model of our study. By comparing the two research models, our study identified ways to improve their explanatory power. To achieve these objectives, we established research hypotheses based on literature pertaining to tourist behavior, such as an extended theory of planning behavior, perception of risk, and coping behavior. Given the results from the quantitative analyses, our paper presents theoretical implications for the field of tourist behavior that are of practical importance for the management of environment-friendly tourism destinations, such as national parks, and presents future research that is needed because of the limitations of this research.

\section{Literature Review}

\subsection{COVID-19 and Perception of Risk}

Risk is perceived if there is a possibility that the goods and services provided may be harmful or have undesirable consequences [32]. People intuitively feel danger, which is called perception of risk [33]. The previous literature proposes that a risk is perceived not objectively and probabilistically, but subjectively in a specific situation [34]. For tourism, perception of risk is described as the anxiety that tourists experience while purchasing and consuming tourism products and services [35]. Likewise, the definition of the perception of risk from COVID-19 from the research model of our study is the subjective anxiety of 
an individual when he or she visits national parks during the pandemic. When tourists perceive a high risk while searching for information before visiting a tourism destination, they are influenced by their cares and worries, thereby influencing their satisfaction with and loyalty to tourism products and destinations [36-38].

In the previous literature, the factors that caused tourists to perceive danger were classified into seven categories: health, political instability, terrorism, unfamiliar food, cultural barriers, national political or religious doctrine, and misdemeanors [39]. Likewise, Dolnicar (2005) [40] claimed that risks consist of political risks, such as terrorism, political instability, and military conflicts; environmental risks, such as natural disasters and landslides, and difficulties with accessing hospitals; physical risks, such as life-threatening diseases and possible unmet needs of clean food and water; risks in planning because of unreliable aviation and inexperienced operators; and financial risks, such as theft and loss of luggage. The biggest constraint on tourist behavior in 2020 was the spread of COVID-19, which is expected to continue throughout 2021 at least. Infectious diseases-included by many studies on risk perception in the tourism sector [39-41] — are assumed to be a major constraint on tourist behavior. As a recent example, compared to the period of January to June 2019, the number of visitors to major tourism spots in Korea in 2020 decreased by $40-60 \%$ in various regions, which shows an unprecedented shock to the whole tourism industry [42].

On the other hand, the decrease in visitors to national parks differs from the decreases in other at tourism destinations. According to the Korea National Park Service (2021) [43], the number of visitors to national parks in 2020 decreased by $19.2 \%$, from 19,899,596 to $16,081,996$, compared with January to June 2019 , which needs attention by researchers, because that is a relatively small decrease compared to the decreases in tourism to other destinations. This was because travel was suppressed in the aftermath of COVID-19 and was replaced by outdoor recreation, which is judged to be comparatively safe. People are coping by means of strategies for risk reduction: tourists tend to avoid purchasing tourism products when the risk perceived by them exceeds a permissible level [30,44-46].

\subsection{Extended Theory of Planned Behavior}

The theory of planned behavior (TPB) by Ajzen (1991) [22] was proposed by extending the Fishbein and Ajzen's (1975) [47] theory of reasoned action (TRA) [24]. It has often been referred to in studies on the decision-making process in which individuals displayed specific behaviors by means of a few variables, such as attitude, subjective norms, and perceived behavioral control [42,48]. As addressed earlier, each of the constructs from the theory of planned behavior is briefly explained as follows. The definition of attitude is a positive or negative assessment of specific conduct determined by an individual. Subjective norms are defined to be positive or negative opinions about specific conduct that a group has in a society. Perceived behavioral control is defined to be the perceived level of ease or difficulty an individual feels in regard to specific conduct [22]. The theory of planned behavior is the dominant theory that accounts for human behavior in many fields, such as health, learning, consumer, environment friendliness, and tourism [18,19,25,49-53]. Even though this is not always the case, the low explanatory power of three independent variables including attitude, subjective norms, and perceived behavioral control, for behavioral intentions [54-57], has sometimes led to other independent variables being added to extend the theory and strengthen its explanatory power for human behavior [58]. Even when many additional predictors are added to the theory though, there is the possibility of providing no improvement to the theory. Nevertheless, we created an extended theory of planned behavior which includes perception of risk from COVID-19, plus coping behavior and sustainable intention to visit. We then proved its validity by finding that is has more explanatory power than the original theory of planned behavior $[20,23,59]$. Although when a new independent or mediating variable is added to the original theory, it is a radical change-for example, how the model of goal directed behavior is distinguished from the theory of planned behavior-we also attempted to extend and investigate the theory [60]. 
Previous literature has increased the understanding of tourist behavior and has encouraged the development of theories that apply micro-psychological factors, such as past experience, prior knowledge, motivation, imagination, pleasure, and involvement; and external environmental factors, such as risk perception, structural constraints, and social class, to the expansion of the theory of planned behavior [21,61-68]. A few previous studies that have expanded the theory of planned behavior by using risk perception have continued to verify the significance of risk perception as an antecedent variable that affects major variables from the theory [67]. As examples of representative studies, Yoon et al. (2010) [69] argued for the significance of the relationship between perceived risk and attitude in overseas travel, and Quintal et al. (2010) [67] claimed that risk perception by outbound travelers from Korea, Japan, and China had a significant effect on their attitudes. Additionally, Lee and Kim (2017) [70] maintained that the perception of risk from fine dust had a significant effect on attitudes and subjective norms toward outdoor recreation activities. Both studies on the positive relationship between risk perception and risk-reducing behavior, and research on coping behavior led by psychological variables derived from attitudes formed by experiencing risks, imply that a study on the expansion of the theory of planned behavior with variables of risk perception and coping behavior about COVID-19 would be significant $[31,34,71-74]$.

\subsection{Coping Behavior}

Manning (1986) [75] asserted that due to excessive demand for tourism destinations in the congestion model, those tourists who perceive congestion tend to choose other destinations [76]. Dissatisfaction derived from congestion leads either to visiting less-congested areas, or to becoming a "congestion avoider" who gives up on individual tourism [29]. Many such studies on coping behavior have defined behaviors of searching for and moving to less-congested destinations and travelling to completely different areas [77-80]. The coping behavior from the congestion model provides substantial implications for outdoor recreation destinations, such as national parks, which have had many visitors even in the aftermath of COVID-19. Given these implications, follow-up research is required to verify the causal relationship between risk-reducing behaviors, such as how tourists respond when they are in danger by adjusting their behaviors, such as refraining from travel or avoiding crowded places, to decrease perceived risk [72,81-83].

The coping behavior of visitors to national parks related to the perception of risk of COVID-19 in our study is defined as an effort to reduce factors of risk on trails. The major social-distancing and quarantine measures used to respond to COVID-19, in addition to the mandatory wearing of masks, were to reduce congestion in specific destinations or to minimize face-to-face contact according to each stage (weak stage 1 to strong stage 3), but tourists at parks can essentially make their own guidelines to cope with the risks [84-86]. Individuals as tourists or consumers come up with their own countermeasures to reduce risks $[31,34,71,72]$ which can be described as "behavior for risk reduction" or "strategies for risk reduction." Risk reduction also occurs when consumers make purchases in a way that reduces uncertainty or dissatisfaction by using strategies to minimize adverse outcomes and to abate potential risks [87].

\section{Methods}

\subsection{Research Model and Hypotheses}

Given the previous studies, a research model was developed to explain tourists' sustainable intention to visit a national park, and seven hypotheses were established (Figure 1). Hypotheses 1-3 explain that perception of risk of contracting COVID-19 has a significant effect on attitude, subjective norms, and perceived behavioral control $[67,69]$. 


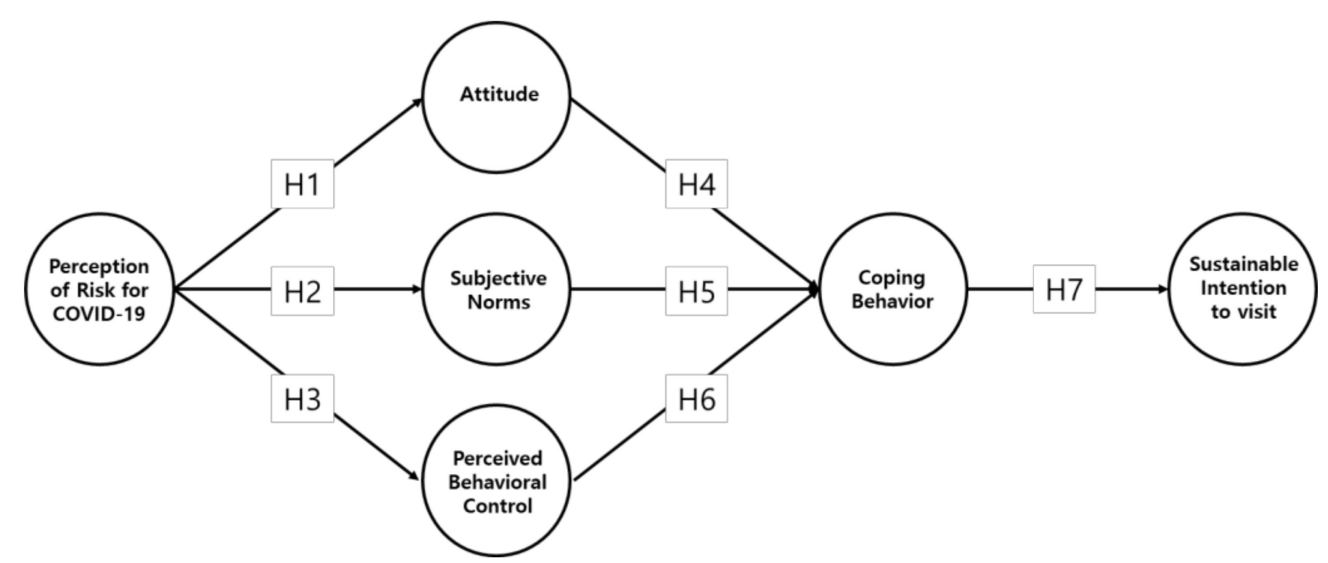

Figure 1. Research model.

Hypothesis 1. (H1): Perception of risk from COVID-19 significantly affects attitude.

Hypothesis 2. (H2): Perception of risk from COVID-19 significantly affects subjective norms.

Hypothesis 3. (H3): Perception of risk from COVID-19 significantly affects perceived behavioral control.

Hypotheses 4-6 propose that attitude, subjective norms, and perceived behavioral control significantly influence coping behavior. These were established based on extant discussion on the relationships between psychological variables such as attitude and coping behavior $[10,73,74,88]$. Additionally, hypothesis 7 was developed to find out whether coping behavior has a significant effect on sustainable intention to visit. Our definition of a sustainable intention to visit is a continuous intention to visit national parks.

Hypothesis 4. (H4): Attitude significantly affects coping behavior.

Hypothesis 5. (H5): Subjective norms significantly affect coping behavior.

Hypothesis 6. (H6): Perceived behavioral control significantly affects coping behavior.

Hypothesis 7. (H7): Coping behavior significantly affects sustainable intention to visit.

\subsection{Data Collection and Analytical Methods}

\subsubsection{Instrument}

The questionnaire was composed of 36 questions, accounting for the six variables presented in the hypotheses and the demographic variables of the sample. The measurement items were derived from the literature review and were determined after discussion and revision of items with three professionals in the tourism field. Specifically, the five items for measuring perception of risk from COVID-19 were reconstructed by extracting variables for health threats [30,39-41]. The three items for measuring coping behavior were adapted from research on congestion avoidance $[89,90]$. Finally, the items about the theory of planned behavior, such as attitude, subjective norms, perceived behavioral control, and visiting intention, were adapted from other extant studies [13,22,23,42,91,92].

\subsubsection{Data Collection and Statistical Tools}

The survey was conducted at parking lots at the entrance to Boriam, which is located in Hallyeohaesang National Park, Namhae-Gun, Korea. In 1968, Hallyeohaesang National Park was designated as the fourth national park in Korea. This park is a treasure trove of marine ecosystems in which large and small islands and natural sceneries harmonize. The total area of the park is $545.63 \mathrm{~km}^{2}$, and $72.3 \%$ of the total consists of sea area 
(https:/ / english.knps.or.kr/, accessed on 15 July 2020). Boriam is the only mountain park in Korea located within $650 \mathrm{~m}$ of the Hallyeohaesang National Park and can be accessed within an hour from surrounding cities, such as Yeosu, Gwangyang, Suncheon, Sacheon, Jinju, Namhae, and Tongyeong. It is recognized as a place where visitors can enjoy their stays while complying with COVID-19 measures, because there is not a dense dining zone as is commonly found in the national park areas in Korea. The survey was conducted on 26 to 27 September 2020, targeting visitors who were over 20 years old, in cooperation with the Hallyeohaesang National Park Office. Visitors were intercepted and asked to answer the questionnaires by ten trained interviewers. The survey was self-administered with a convenient sampling method. A total of 370 questionnaires were distributed and collected. Of these, 351 samples were used for the analyses, excluding 19 unusable samples with missing values. Data analyses were performed using SPSS Statistics version 23 and AMOS 18.0. The validity of the measurement variables was tested by means of confirmatory factor analysis and correlation analysis. The reliability was tested using Cronbach's alpha. Both testing the research hypotheses and comparing the two research models were conducted by structural equation modelling. Additionally, the parsimonious fit index (PFI) and squared multiple correlations (SMC) were calculated to identify significant improvements from the two research models.

\section{Results}

\subsection{Demographic Information of the Sample}

Frequency analysis was conducted to identify demographic characteristics, which included gender, residence, age, occupation, monthly income, and educational level, of the 351 usable subjects (Table 1). For gender, there was no significant difference between males $(50.7 \%)$ and females $(49.3 \%)$ in their proportions of respondents, and their ages showed an even distribution that ranged from the 20 s to over $60 \mathrm{~s}$. The most common monthly income included 130 respondents $(37.0 \%)$, who made more than 5000 USD, followed by the group making 4000-5000 USD comprising 83 respondents (23.6\%). In occupation, the most common group was 83 respondents $(23.6 \%$ ) with employees, followed by 52 respondents $(14.8 \%)$ who were professionals or housewives. Regarding the educational level of the respondents, the most common group comprised those with 4-year college degrees ( 80 respondents, $55.4 \%$ ), followed by the group with 2-year college degrees (37 respondents, $25.2 \%)$. For place of residence, Kyungnam, adjacent to the survey location, was the most common, with 30 respondents $(20.4 \%)$, followed by 13 respondents $(8.8 \%)$ from Jeonnam, and 11 respondents (7.5\%) from Busan.

Table 1. Demographic characteristics of the sample.

\begin{tabular}{|c|c|c|c|c|c|}
\hline & Item & $n(\%)$ & & Item & $n(\%)$ \\
\hline \multirow{2}{*}{ Gender } & Male & $178(50.7)$ & \multirow{4}{*}{$\begin{array}{c}\text { Educational } \\
\text { level }\end{array}$} & Under high school & $16(10.2)$ \\
\hline & Female & $173(49.3)$ & & 2-year college & $37(25.2)$ \\
\hline \multirow{5}{*}{ Age } & $20 \mathrm{~s}$ & $75(21.4)$ & & 4-year college & $80(55.4)$ \\
\hline & $30 \mathrm{~s}$ & $54(15.4)$ & & graduate & $14(9.5)$ \\
\hline & $40 \mathrm{~s}$ & $71(20.2)$ & \multirow{9}{*}{ Residence } & Seoul & $8(5.4)$ \\
\hline & $50 \mathrm{~s}$ & $91(25.9)$ & & Busan & $11(7.5)$ \\
\hline & More than $60 \mathrm{~s}$ & $60(17.1)$ & & Daegu & $12(8.2)$ \\
\hline \multirow{6}{*}{$\begin{array}{l}\text { Monthly } \\
\text { income }\end{array}$} & Less than 1000 USD & $4(1.1)$ & & Incheon & $5(3.4)$ \\
\hline & 1000-2000 USD & $13(3.7)$ & & Gwangju & $7(4.8)$ \\
\hline & 2000-3000 USD & $54(15.4)$ & & Daejeon & $8(5.4)$ \\
\hline & 3000-4000 USD & $67(19.1)$ & & Ulsan & $6(4.1)$ \\
\hline & 4000-5000 USD & $83(23.6)$ & & Kyounggi & $12(8.2)$ \\
\hline & More than 5000 USD & $130(37.0)$ & & Kangwon & $3(2.0)$ \\
\hline
\end{tabular}


Table 1. Cont.

\begin{tabular}{|c|c|c|c|c|}
\hline & Item & $n(\%)$ & Item & $n(\%)$ \\
\hline \multirow{8}{*}{ Occupation } & Self-employer & 41 (11.7) & Chungbuk & $4(2.7)$ \\
\hline & Professional & $52(14.8)$ & Chungnam & $8(5.4)$ \\
\hline & Official & $44(12.5)$ & Jeonbuk & $11(7.5)$ \\
\hline & Farmer/fisherman & $14(4.0)$ & Jeonnam & $13(8.8)$ \\
\hline & Student & $33(9.4)$ & Kyungbuk & $5(3.4)$ \\
\hline & Housewife & $52(14.8)$ & Kyungnam & $30(20.4)$ \\
\hline & Employee & 83 (23.6) & Jeju & $1(0.7)$ \\
\hline & Others & $32(9.1)$ & Sejong & $3(2.0)$ \\
\hline
\end{tabular}

\subsection{Validity and Reliability of Measurements}

As shown in Table 2, the confirmatory factor analysis to verify the validity of the measurement items showed that the fit index of the measurement model was $\chi^{2} / \mathrm{df}=2.493$ $\left(\chi^{2}=760.377, \mathrm{df}=305\right), \mathrm{RMR}=0.043, \mathrm{RMSEA}=0.064, \mathrm{GFI}=0.869, \mathrm{NFI}=0.907$, $\mathrm{RFI}=0.893, \mathrm{IFI}=0.943, \mathrm{TLI}=0.934$, and CFI $=0.943$, thereby meeting the statistical criteria. In general, the recommended criteria for the fit index are presented as $\chi^{2} / \mathrm{df}$ $<3$, RMSEA $<0.08$, RMR $<0.05$, GFI, NFI, TLI, CFI $>0.9$ [93,94]. After verification of the convergent validity of the measurement items, one of the items used to measure the perception of risk from COVID-19 did not meet the criterion (0.5-0.95) and so was deleted. The deleted item was about whether "there was an atmosphere of refraining from visiting the national park because of COVID-19," showing 0.375 of the factor loading.

Table 2. Convergent validity and reliability of the measurements.

\begin{tabular}{|c|c|c|c|c|c|c|c|}
\hline Factor & Items & S.E. & $t$ & $\begin{array}{l}\text { Standardized } \\
\text { Coefficients }\end{array}$ & AVE & CR & $\begin{array}{l}\text { Cronbach's } \\
\alpha\end{array}$ \\
\hline \multirow{4}{*}{$\begin{array}{l}\text { Perception of } \\
\text { Risk for } \\
\text { COVID-19 }\end{array}$} & $\begin{array}{l}\text { Trails of the national park are not safe } \\
\text { from COVID-19 }\end{array}$ & 0.080 & $11.705^{* * *}$ & 0.652 & \multirow{4}{*}{0.609} & \multirow{4}{*}{0.861} & \multirow{4}{*}{0.812} \\
\hline & $\begin{array}{l}\text { There is insufficient information on } \\
\text { visiting the national park under } \\
\text { COVID-19 }\end{array}$ & 0.074 & $13.479 * * *$ & 0.747 & & & \\
\hline & $\begin{array}{l}\text { There are concerns about the } \\
\text { quarantine and hygiene conditions of } \\
\text { indoor facilities such as restrooms and } \\
\text { shelters in the national park }\end{array}$ & 0.084 & $14.743^{* * *}$ & 0.839 & & & \\
\hline & $\begin{array}{c}\text { There are not enough tour programs } \\
\text { where visitors can safely participate in } \\
\text { under COVID-19 }\end{array}$ & - & - & 0.771 & & & \\
\hline \multirow{5}{*}{ Attitude } & I like to visit the national park & 0.050 & $20.404^{* * *}$ & 0.869 & \multirow{5}{*}{0.865} & \multirow{5}{*}{0.970} & \multirow{5}{*}{0.950} \\
\hline & I am happy to visit the national park & 0.040 & $23.797 * * *$ & 0.869 & & & \\
\hline & $\begin{array}{l}\text { I am positive about visiting the } \\
\text { national park }\end{array}$ & 0.037 & $25.453^{* * *}$ & 0.893 & & & \\
\hline & Visiting the national park is worthwhile & 0.037 & $27.460 * * *$ & 0.922 & & & \\
\hline & $\begin{array}{l}\text { Visiting the national park will give me } \\
\text { good outcomes. }\end{array}$ & - & - & 0.896 & & & \\
\hline \multirow[b]{2}{*}{$\begin{array}{l}\text { Subjective } \\
\text { Norm }\end{array}$} & $\begin{array}{c}\text { My family thinks positively about my } \\
\text { visit to the national park }\end{array}$ & 0.045 & $18.073^{* * *}$ & 0.768 & \multirow[b]{2}{*}{0.837} & \multirow[b]{2}{*}{0.968} & \multirow[b]{2}{*}{0.950} \\
\hline & $\begin{array}{l}\text { My friends think positively about my } \\
\text { visit to the national park }\end{array}$ & 0.041 & $23.588^{* * * *}$ & 0.880 & & & \\
\hline
\end{tabular}


Table 2. Cont.

\begin{tabular}{|c|c|c|c|c|c|c|c|}
\hline Factor & Items & S.E. & $t$ & $\begin{array}{l}\text { Standardized } \\
\text { Coefficients }\end{array}$ & AVE & $\mathrm{CR}$ & $\begin{array}{l}\text { Cronbach's } \\
\alpha\end{array}$ \\
\hline & $\begin{array}{l}\text { My acquaintances think positively } \\
\text { about my visit to the national park }\end{array}$ & 0.040 & $25.202^{* * *}$ & 0.907 & & & \\
\hline & $\begin{array}{l}\text { My family will want me to visit the } \\
\text { national park }\end{array}$ & 0.042 & $23.257^{* * *}$ & 0.874 & & & \\
\hline & $\begin{array}{l}\text { My friends will want me to visit the } \\
\text { national park }\end{array}$ & - & - & 0.885 & & & \\
\hline & $\begin{array}{l}\text { My acquaintances will want me to visit } \\
\text { the national park }\end{array}$ & 0.030 & $32.685^{* * *}$ & 0.870 & & & \\
\hline \multirow{5}{*}{$\begin{array}{c}\text { Perceived } \\
\text { Behavioral } \\
\text { Control }\end{array}$} & $\begin{array}{l}\text { I can visit the national park whenever I } \\
\text { want }\end{array}$ & 0.088 & $13.907^{* * *}$ & 0.798 & \multirow{5}{*}{0.636} & \multirow{5}{*}{0.897} & \multirow{5}{*}{0.865} \\
\hline & $\begin{array}{l}\text { I am financially able to afford to visit } \\
\text { the national park }\end{array}$ & 0.077 & $13.735^{* * *}$ & 0.787 & & & \\
\hline & $\begin{array}{l}\text { I have enough time to visit the national } \\
\text { park }\end{array}$ & 0.088 & $13.460^{* * *}$ & 0.770 & & & \\
\hline & $\begin{array}{l}\text { It is easy to learn necessary skills for } \\
\text { visiting the national park }\end{array}$ & 0.086 & $11.929^{* * *}$ & 0.680 & & & \\
\hline & $\begin{array}{l}\text { I can easily find the information about } \\
\text { visiting the national park }\end{array}$ & - & - & 0.717 & & & \\
\hline \multirow{3}{*}{$\begin{array}{l}\text { Sustainable } \\
\text { Intention to } \\
\text { Visit }\end{array}$} & $\begin{array}{l}\text { I will try to continue to visit the } \\
\text { national park }\end{array}$ & 0.039 & $25.448^{* * *}$ & 0.927 & \multirow{3}{*}{0.887} & \multirow{3}{*}{0.959} & \multirow{3}{*}{0.921} \\
\hline & $\begin{array}{l}\text { I will recommend visiting the national } \\
\text { park to others }\end{array}$ & 0.036 & $22.871^{* * *}$ & 0.873 & & & \\
\hline & $\begin{array}{l}\text { I am sure I will continue to visit the } \\
\text { national park }\end{array}$ & - & - & 0.885 & & & \\
\hline \multirow{3}{*}{$\begin{array}{l}\text { Coping } \\
\text { Behavior }\end{array}$} & $\begin{array}{l}\text { I will choose trails that are expected to } \\
\text { have fewer visitors. }\end{array}$ & 0.102 & $12.585^{* * *}$ & 0.717 & \multirow{3}{*}{0.678} & \multirow{3}{*}{0.863} & \multirow{3}{*}{0.786} \\
\hline & $\begin{array}{l}\text { I will minimize to spend time where } \\
\text { other visitors gather on trails }\end{array}$ & 0.113 & $11.687^{* * *}$ & 0.849 & & & \\
\hline & $\begin{array}{l}\text { When visiting, I will try to comply with } \\
\text { the rules on COVID-19 }\end{array}$ & - & - & 0.708 & & & \\
\hline
\end{tabular}

${ }^{* * *} p<0.000$

As a result of re-conducting the confirmatory factor analysis after removing the questionnaire item that did not meet the criterion of factor loading, the fit index of the measurement model was $\chi^{2} / \mathrm{df}=2.420\left(\chi^{2}=677.548, \mathrm{df}=208\right), \quad \mathrm{RMR}=0.031$, RMSEA $=0.064, \mathrm{GFI}=0.874, \mathrm{NFI}=0.913, \mathrm{RFI}=0.901, \mathrm{IFI}=0.947, \mathrm{TLI}=0.938$, and $\mathrm{CFI}=0.947$, showing that most of the fit indices improved slightly. The convergent validity was suitable for the model, because all values of composite reliability (CR), factor loading, and average variation extracted (AVE) for each measurement were higher than the criteria. Additionally, correlation analysis between measurement items, as shown in Table 3, showed that the correlation coefficients between measurement items were between 0.100 and 0.769 , thereby meeting the recommended criterion of 0.85 [95]. The AVEs of each measurement item were larger than the squared values of the correlation coefficients, confirming that there was discriminant validity $[96,97]$. 
Table 3. Correlations between measurements.

\begin{tabular}{|c|c|c|c|c|c|c|c|}
\hline Category & $\begin{array}{l}\text { Perception } \\
\text { of Risk for } \\
\text { COVID-19 }\end{array}$ & Attitude & $\begin{array}{c}\text { Subjective } \\
\text { Norms }\end{array}$ & $\begin{array}{c}\text { Perceived } \\
\text { Behavioral } \\
\text { Control }\end{array}$ & $\begin{array}{l}\text { Coping } \\
\text { Behavior }\end{array}$ & $\begin{array}{c}\text { Sustainable } \\
\text { Intention to } \\
\text { Visit }\end{array}$ & AVE \\
\hline $\begin{array}{l}\text { Perception of } \\
\text { Risk for } \\
\text { COVID-19 }\end{array}$ & 1 & & & & & & 0.609 \\
\hline Attitude & $\begin{array}{l}-0.201 \\
(0.040)\end{array}$ & 1 & & & & & 0.865 \\
\hline $\begin{array}{l}\text { Subjective } \\
\text { Norms }\end{array}$ & $\begin{array}{l}-0.100 \\
(0.010) \\
\end{array}$ & $\begin{array}{c}0.769 \\
(0.591) \\
\end{array}$ & 1 & & & & 0.837 \\
\hline $\begin{array}{c}\text { Perceived } \\
\text { Behavioral } \\
\text { Control }\end{array}$ & $\begin{array}{l}-0.236 \\
(0.056)\end{array}$ & $\begin{array}{c}0.667 \\
(0.445)\end{array}$ & $\begin{array}{c}0.623 \\
(0.388)\end{array}$ & 1 & & & 0.636 \\
\hline $\begin{array}{l}\text { Coping } \\
\text { behavior }\end{array}$ & $\begin{array}{c}0.122 \\
(0.015) \\
\end{array}$ & $\begin{array}{c}0.390 \\
(0.152) \\
\end{array}$ & $\begin{array}{c}0.402 \\
(0.162) \\
\end{array}$ & $\begin{array}{c}0.371 \\
(0.138) \\
\end{array}$ & 1 & & 0.678 \\
\hline $\begin{array}{c}\text { Sustainable } \\
\text { Intention to } \\
\text { visit }\end{array}$ & $\begin{array}{l}-0.114 \\
(0.013)\end{array}$ & $\begin{array}{c}0.604 \\
(0.365)\end{array}$ & $\begin{array}{c}0.620 \\
(0.384)\end{array}$ & $\begin{array}{c}0.637 \\
(0.406)\end{array}$ & $\begin{array}{c}0.567 \\
(0.321)\end{array}$ & 1 & 0.887 \\
\hline
\end{tabular}

Note: () denotes the square of the correlation coefficient.

\subsection{Testing the Hypotheses}

Structural equation modeling was performed to verify research hypotheses 1-7 with the entire sample $(n=351)$ (Table 4). To begin with, by assessing the values of $\chi^{2} / \mathrm{df}$, RMR, CFI, TLI, RMSEA, and NFI, which are commonly provided to evaluate the fit of a structural model, it was found that they all met the criteria. Testing the research hypotheses showed that the perception of risk of COVID-19 had a significant effect on both attitude and perceived behavioral control; hence, hypotheses 1 and 3 were accepted. Hypothesis 2, however, was rejected, because the perception of risk of COVID-19 did not significantly influence subjective norms. From these results, we assume that the perception of risk of COVID-19 has a negative effect on the psychological variables of individuals, such as attitudes and perceived behavioral control toward visiting national parks, eventually leading to a decrease in visitors.

Table 4. Results of testing hypotheses by means of SEM.

\begin{tabular}{cccccc}
\hline & Path & Estimate & S.E. & $t$ & $p$ \\
\hline H1 & Perception of Risk for COVID-19 $\rightarrow$ Attitude & -0.202 & 0.061 & $-3.410 * * *$ & 0.000 \\
\hline H2 & Perception of Risk for COVID-19 $\rightarrow$ Subjective Norm & -0.101 & 0.061 & -1716 & 0.086 \\
\hline H3 & Perception of Risk for COVID-19 $\rightarrow$ Perceived Behavioral Control & -0.233 & 0.055 & $-3.755^{* * *}$ & 0.000 \\
\hline H4 & Attitude $\rightarrow$ Coping Behavior & 0.187 & 0.059 & $2.184^{*}$ & 0.029 \\
\hline H5 & Subjective Norm $\rightarrow$ Coping Behavior & 0.304 & 0.057 & $3.685^{* * *}$ & 0.000 \\
\hline H6 & Perceived Behavioral Control $\rightarrow$ Coping Behavior & 0.344 & 0.062 & $4.517^{* * *}$ & 0.000 \\
\hline H7 & Coping Behavior $\rightarrow$ Sustainable Intention to Visit & 0.870 & 0.113 & $11.604^{* * *}$ & 0.000 \\
\hline
\end{tabular}

$$
{ }^{*} p<0.05,{ }^{* * *} p<0.001 \text {. }
$$

Among the major variables of the theory of planned behavior, subjective norms and perceived behavioral control had significant effects on coping behavior; hence, hypotheses 5 and 6 were accepted. As the effect of perceived behavioral control is the highest estimate, the result from our study parallels those in previous studies [13,23,67,98-100]. As attitude did not significantly affect coping behavior, however, hypothesis 4 was rejected. What our study indicates is that hypotheses 4 and 5 explain whether attitude and subjective 
norms significantly affect coping behavior, as mirrored in the distinct case of the COVID-19 pandemic. In particular, what our study found by testing hypothesis 4 differs from the results in a few other studies in which the theory of planned behavior was applied. That is, if an individual belongs to a particular group, the dynamics and norms within the group allow less freedom in the individual's attitudes and behaviors [100-102]. The concern that an infectious disease might spread to the affiliated group functioned as a norm, thereby weakening individual free will-for instance, via attitude.

Mayo and Jarvis (1982) [103] also argued that the influence of an individual's attitude may be unstable, depending on particular circumstances, and that the opinion of the affiliated group can influence individual behavior in order to be faithful to the role assigned to society. The interaction between the subjective norms and coping behavior proposed in hypothesis 5 can be accounted for in a similar context. SARS-CoV-2 has primarily infected groups with close social relationships, such as family, friends, and work. Decision making by the affiliated group, therefore, plays an important role in participating in particular tourism activities. The result of testing hypothesis 6 was an optimistic bias that individuals are relatively safe from risks that may occur in tourism destinations [41,104]. In the field of health and environment, there is literature showing that the level of perception that risks can be controlled by individuals is more common than in the field of safety accidents $[30,105]$. Last, because coping behavior had a significant effect on sustainable intention to visit the national park, hypothesis 7 was accepted.

\subsection{Testing the Research Model Fit}

The research model (Model B) for our study was compared with the base model (Model A) by adding coping behavior as a variable to the theory of planned behavior during the COVID-19 pandemic. Parsimonious fit index (PFI) and squared multiple correlations (SMC) were derived to verify and compare the two research models. When the two models were compared after a variable of coping behavior was added to the research model in our study, one index of the PFIs was found to be better, and the SMC was significantly improved (see Table 5). The PFI can be used as a criterion for judging which of two or more research models is more suitable in a case where the research model is complicated due to the addition of variables [106,107]. The PFIs such as parsimonious goodness of fit index (PGFI), parsimonious normed fit index (PNFI), parsimonious comparative fit index (PCFI), and Akaike information criterion (AIC) are provided as criteria for determining the research model's fit. Note that in each of those cases, the lower the value, the better the research model [108]. Additionally, the SMC refers to the proportion of the total variation explained by the model [109]. Resultantly, the research model of our study (Model B) had higher PGFI and AIC than the basic research model (Model A), though two models presented the same PCFI. For our research model, the PNFI was lower, and the SMC that explains sustainable intention to visit was $75.6 \%$, which was higher than that of the extant research model (49.4\%). The research model, therefore, that accounts for sustainable intention to visit the national park under the COVID-19 pandemic, achieved a similar PFI value to that of the basic research model, despite the addition of a variable which is coping behavior. Additionally, the suitability of the Model B was verified because the SMC was improved. 
Table 5. Results of testing the research model's fit.

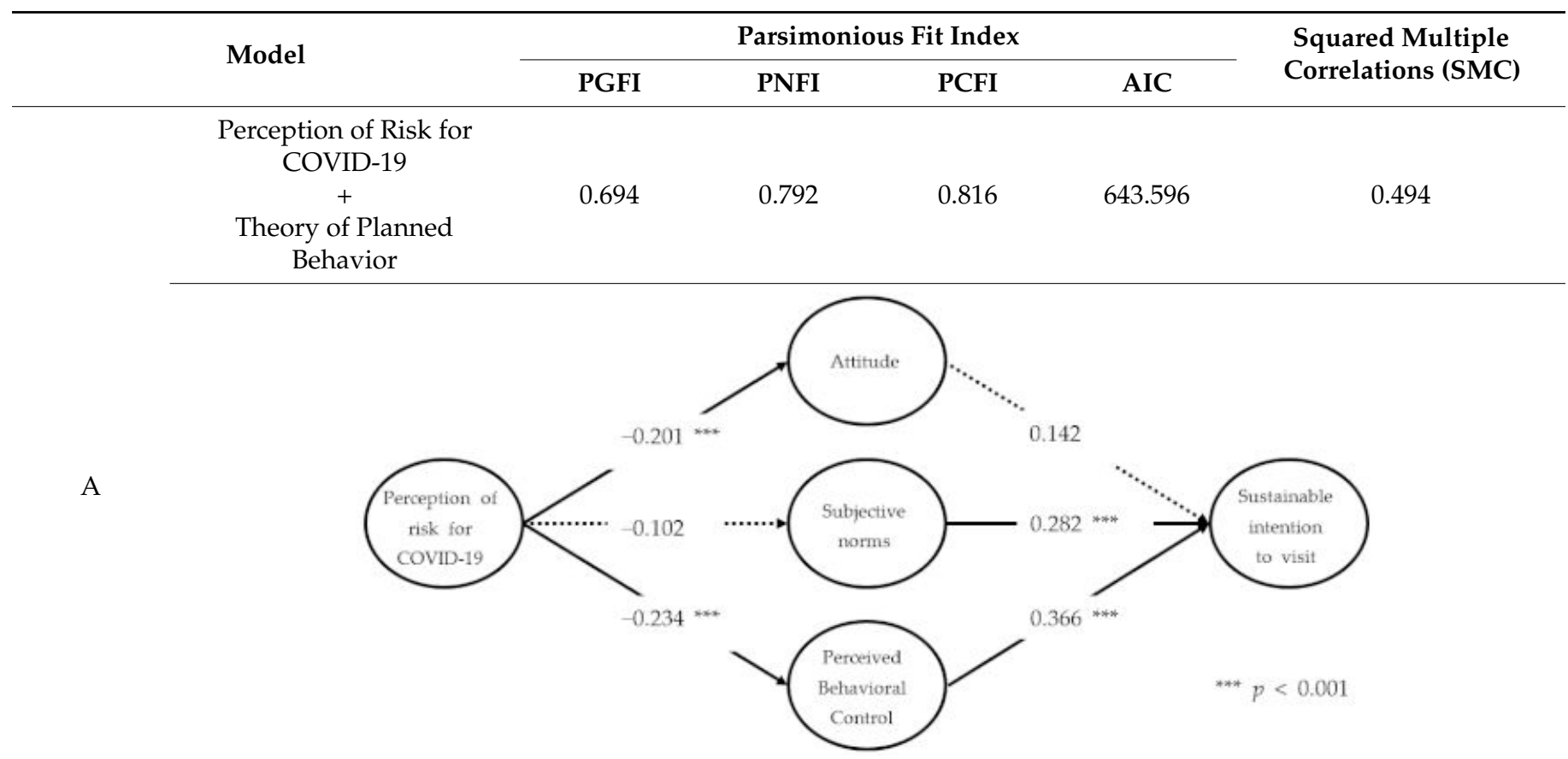

Goodness of fit for the model: $\chi^{2} / \mathrm{df}=2.424, \mathrm{RMR}=0.027, \mathrm{CFI}=0.956, \mathrm{TLI}=0.948, \mathrm{RMSEA}=0.064, \mathrm{NFI}=0.928$

Perception of Risk for COVID-19

$$
+
$$

Theory of Planned

Behavior

0.698

0.787

797.152

0.756

$+$

Coping Behavior

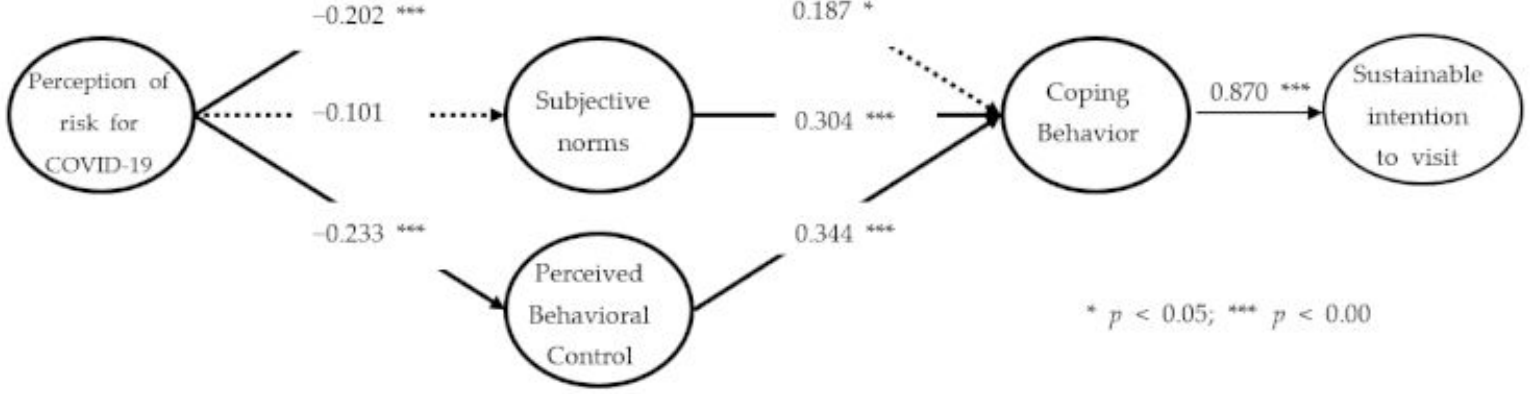

Goodness of fit for the model: $\chi^{2} / \mathrm{df}=2.341, \mathrm{RMR}=0.037, \mathrm{CFI}=0.950, \mathrm{TLI}=0.942, \mathrm{RMSEA}=0.062, \mathrm{NFI}=0.916$

Note: A denotes the prior research model, and B denotes the research model in our study.

\section{Conclusions}

Our study originated in a research question about why visitors continue to visit natural destinations such as national parks during the COVID-19 pandemic. In addition, the purpose of our study was to analyze an extended research model of whether visitors intend to continue to visit a certain national park by minimizing individual risks by means of coping behavior, such as walking on less-congested trails and minimizing face-to-face contact. A research model was developed to explain the relationships among perception of risk, variables from the theory of planned behavior, and coping behavior based on 
previous studies [10]. After seven hypotheses originating from the research model were established, they were tested. Five were accepted. Perception of risk of COVID-19 had a significant effect on attitude and perceived behavioral control. Subjective norms and perceived behavioral control had significant effects on coping behavior. Finally, there was a significant relationship between coping behavior and sustainable intention to visit. The conclusions and theoretical implications of our study are as follows.

First, in both models, the perception of risk of COVID-19 had a negative effect on both attitude and perceived behavioral control, which are psychological variables that either directly or indirectly induce behaviors. This implies that the results are linked to reasons for the decrease in visitors to many tourism destinations, including national parks, during the worldwide pandemic. The perception of risk of COVID-19 did not significantly affect the subjective norms in either model, which indicates that, because subjective norms are the thoughts by those members of particular groups, the perception of risk of COVID-19 is not an independent variable that can explain the subjective norms. Second, in Model A, attitude did not have a significant effect on sustainable intention to visit, whereas the subjective norms did have a significant effect on sustainable intention to visit. These results imply that the influential factor that sustains an intention to visit during the COVID-19 pandemic is an evaluation of the given surroundings, such as by subjective norms, not the temporarily impotent attitude. The social attitude that outdoor natural tourism destinations such as national parks are safer than indoor counterparts is delivered to the affiliated group, thereby making tourism activities available.

Third, perceived behavioral control in Model A had the greatest influence on sustainable intention to visit, apparently because visitors with perceived behavioral control decide to visit safer national parks rather than other destinations, even during the COVID19 pandemic. Boriam in Hallyeohaesang National Park, which was the location of data collection, is a destination that residents in a few cities near Boriam can easily visit in daily life with their vehicles. It consists of trails that facilitate self-control measures, such as by social distancing, due to their relatively low congestion, which indicates that the perceived behavioral control of knowing about trails is a major factor in visiting national parks.

Fourth, testing the fit of Model B showed that adding explanatory variables to the variables already included in the extant theory should be continued for human planned behavior. The expansion of the theory of planned behavior applied in our study began from a criticism of the low explanatory power of three variables: attitude, subjective norms, and perceived behavioral control [54,57]. Despite the addition of two variables-perception of risk and coping behavior for COVID-19-the PFI of Model B reached a favorable level, and an improvement in explanatory power was a result consistent with the original purpose of expanding the theory of planned behavior. In particular, although the variable of coping behavior in Model B helped improve the explanatory power, the question of whether coping behavior fully plays a mediating role between the effects of the original predictors and the intentions remains. Follow-up studies are necessary to identify direct and indirect effects of predictors on the intentions in the proposed models. Furthermore, because both the results showed good fit indices from Models A and B, it indicates that both models are available to apply to a special situation as the COVID-19 pandemic. Other studies also tell us the usefulness of the extended theory of planned behavior [110].

In addition, the result from our study that subjective norms and perceived behavioral control have significant effects on coping behavior provides worthwhile clues that explain the psychological changes they drive when visitors come to national parks during the pandemic in the East. The statistics on the number of visitors to national parks in Korea did not show a large decline in visitors compared to other tourism destinations in 2020. This implication needs to be analyzed in more detail in future studies, because it might arise from reasons for choosing natural tourism destinations such as national parks being recognized as relatively safe during the COVID-19 pandemic, having infrastructure that has matured, such as mountaineering and trekking facilities, having online information available, and encouraging those who comply with quarantine rules to visit tourism destinations. 
The results from our study provide not only theoretical, but practical implications for the efficient control and management of visitors to national parks in response to the COVID19 pandemic. First, national parks enable visitors to visit because of the optimistic idea that national parks are safer than are other tourism destinations, and because individuals may know a lot from prior information collection about destinations. Rather than the consistent social distancing mandated by the government based on increases in the number of infected, therefore, what is needed is management of visitors by means of assertive alternatives, such as entry and exit control by time. Second, a natural resource such as a national park can become a means to alleviate the side effects that result in Corona Blues caused by the pandemic [111]. If the quarantine stage of social distancing is eased because of a decrease in the number of the infected, a plan to distribute the number of visitors, for example, by temporarily opening some of the national park trails operated as a nature rest-year system, should also be considered while meeting the needs of visitors. Finally, in order to provide convenience for potential visitors, it is essential to develop a smart application related to congestion management that can support the congestion indexing of individual trails in national parks in real time.

Our study, being empirical, has the following limitations. First, the results cannot be generalized, due to the temporal and spatial limitations. In order to improve the reliability and validity of the results from our study and to generalize them, a longitudinal study should be conducted, not only in Hallyeohaesang National Park where the data collection of our study was conducted in 2020, but also in other national parks in Korea. Additionally, future research that compares the impacts of the COVID-19 pandemic on tourism area before and during COVID-19 will be meaningful [112]. Second, a few particular variables in the research model of our study did not show seamless causal relationships. As recent studies on the COVID-19 pandemic have proliferated in the tourism field and have accumulated, future research to generalize the results from our study should be carried out. Third, questions measuring sustainable intention to visit were not adequate in that a typical question for such an item should be, "I intend to visit the national park." The items such as "I will visit the national park" that have been used in our study could produce a violation of the compatibility of the principles of the theory of planned behavior. These items, therefore, should be revised for adequate measurements in future research. Lastly, no significant effect was found in the relationship between attitude and coping behavior in the research model: $p=0.057$, which is close to the $5 \%$ significance level. It is imperative to further verify whether the results from our study are similar to those in other cases.

Author Contributions: Conceptualization: B.-H.S., Y.C., H.K.; methodology: B.-H.S., Y.C., H.K.; formal analysis: B.-H.S., Y.C., H.K.; investigation: B.-H.S., Y.C., H.K.; writing-original draft preparation: B.-H.S., Y.C., H.K.; writing-review and editing: B.-H.S., Y.C., H.K. All authors have read and agreed to the published version of the manuscript.

Funding: This research received no external funding.

Institutional Review Board Statement: Due to the observational nature of the study, and the absence of any involvement of therapeutic medication, no formal approval of the Institutional Review Board of the local Ethics Committee was required. Nonetheless, all subjects were informed about the study, and participation was fully voluntary. Participants were ensured of confidentiality and anonymity of the information associated with the surveys. The study was conducted according to the guidelines of the Declaration of Helsinki.

Informed Consent Statement: Informed consent was obtained from all subjects involved in the study.

Data Availability Statement: The datasets used in this research are available upon request from the corresponding author. The data are not publicly available.

Conflicts of Interest: The authors declare no conflict of interest. 


\section{References}

1. Hisler, G.C.; Twenge, J.M. Sleep characteristics of US adults before and during the COVID-19 pandemic. Soc. Sci. Med. 2021, 276, 113849. [CrossRef] [PubMed]

2. Kark, A.E.; Kurzer, M.N.; Belsham, P.A. Three thousand one hundred seventy-five primary inguinal hernia repairs: Advantages of ambulatory open mesh repair using local anesthesia. J. Am. Coll. Surg. 1998, 186, 447-455. [CrossRef]

3. Barua, S. Understanding Coronanomics: The Economic Implications of the Coronavirus (COVID-19) Pandemic; MPRA Paper 99693; University Library of Munich: Munich, Germany, 2020.

4. Liu, Y.; Lee, J.M.; Lee, C. The challenges and opportunities of a global health crisis: The management and business implications of COVID-19 from an Asian perspective. Asian Bus. Manag. 2020, 19, 277-297. [CrossRef]

5. Rahman, S.M.; Kim, J.; Laratte, B. Disruption in circularity? Impact analysis of COVID-19 on ship recycling using Weibull tonnage estimation and scenario analysis method. Resour. Conserv. Recycl. 2021, 164, 105139. [CrossRef] [PubMed]

6. Edensor, T. Walking in the British countryside: Reflexivity, embodied practices and ways to escape. Body Soc. 2000, 6, 81-106. [CrossRef]

7. Matteucci, X.; Filep, S. Eudaimonic tourist experiences: The case of flamenco. Leis. Stud. 2017, 36, 39-52. [CrossRef]

8. Bhaskara, G.I.; Filimonau, V. The COVID-19 pandemic and organisational learning for disaster planning and management: A perspective of tourism businesses from a destination prone to consecutive disasters. J. Hosp. Tour. Manag. 2021, 46, 364-375. [CrossRef]

9. Jiony, M.M.; Lew, T.Y.; Gom, D.; Tanakinjal, G.H.; Sondoh, S., Jr. Influence of cultural intelligence and psychological capital on service quality: A study of the hotel industry in Sabah, Malaysia. Sustainability 2021, 13, 10809. [CrossRef]

10. Seong, B.; Lee, S.; Choi, Y. An analysis on the factors affecting a national park persistent visiting intention by adopting the extended theory of planned behavior: Focusing on COVID-19 risk perception and coping behavior. J. Tour. Stud. 2021, 33, 69-90. [CrossRef]

11. Miller, Z.D.; Freimund, W.; Metcalf, E.C.; Nickerson, N.; Powell, R.B. Merging elaboration and the theory of planned behavior to understand bear spray behavior of day hikers in Yellowstone National Park. Environ. Manag. 2019, 63, 366-378. [CrossRef] [PubMed]

12. Reigner, N.; Lawson, S.R. Improving the efficacy of visitor education in Haleakalā National Park using the theory of planned behavior. J. Interpret. Res. 2009, 14, 21-45. [CrossRef]

13. Ajzen, I.; Driver, B.L. Application of the theory of planned behavior to leisure choice. J. Leis. Res. 1992, 24, 207-224. [CrossRef]

14. Chi, X.; Han, H. Emerging rural tourism in China's current tourism industry and tourism behaviors: The case of Anji County. J. Travel Tour. Mark. 2021, 38, 58-74. [CrossRef]

15. Cho, H. An examination of the theory of planned behaviour in the participation and adherence of the golf. The Korean J. of Phys. Educ. 2005, 44, 277-285.

16. Hrubes, D.; Ajzen, I.; Daigle, J. Predicting hunting intentions and behavior: An application of the theory of planned behavior. Leis. Sci. 2001, 23, 165-178. [CrossRef]

17. Park, J.K. Model to describe leisure participation-Application of the model of theory of planned behavior and the model of theory reasoned action. Korean J. Tour. Res. 2011, 26, 237-255.

18. Kim, H. The relationship overseas golf tour of golf player: An application of the theory of planned behavior. J. Sport Leis. Stud. 2009, 35, 237-247. [CrossRef]

19. Warburton, J.; Terry, D.J. Volunteer decision making by older people: A test of a revised theory of planned behavior. Basic Appl. Soc. Psy. 2000, 22, 245-257. [CrossRef]

20. Kim, H.; Lee, T.; Yoon, S. A study on behavioral intention about visiting in theme park based on extended theory of planned behavior: An investigation into the role of playfulness. Int. Jrl. Tour. Hosp. Res. 2010, 24, 5-23.

21. Han, H.; Meng, B.; Kim, W. Emerging bicycle tourism and the theory of planned behavior. J. Sustain. Tour. 2017, 25, 292-309. [CrossRef]

22. Ajzen, I. The theory of planned behavior. Organ. Behav. Hum. Decis. Process. 1991, 50, 179-211. [CrossRef]

23. Seong, B.; Choi, S.D. An analysis on the factors affecting the tourism behavior by adopting the extended theory of planned behavior: Focusing on structural tourism constraints and social classes. J. Tour. Sci. 2014, 38, 79-101.

24. Han, H.; Kim, Y. An investigation of green hotel customers' decision formation: Developing an extended model of the theory of planned behavior. Int. J. Hosp. Manag. 2010, 29, 659-668. [CrossRef]

25. Miesen, H.W. Predicting and explaining literary reading: An application of the theory of planned behavior. Poetics 2003, 31, 189-212. [CrossRef]

26. Rogers, R.W. A protection motivation theory of fear appeals and attitude change. J. Psychol. 1975, 91, 93-114. [CrossRef] [PubMed]

27. Tunner, J.F., Jr.; Day, E.; Crask, M.R. Protection motivation theory: An extension of fear appeals theory in communication. J. Bus. Res. 1989, 19, 267-276. [CrossRef]

28. Maddux, J.E.; Rogers, R.W. Protection motivation and self-efficacy: A revised theory of fear appeals and attitude change. J. Exp. Soc. Psychol. 1983, 19, 469-479. [CrossRef]

29. Seong, B.; Choi, Y. Analysis on the influencing relationship between crowding perception, coping behavior and satisfaction: A case of visitors to Danyang-gun 'Mancheonha Skywalk'. Korean J. Hosp. Tour. 2020, 29, 163-175. [CrossRef] 
30. Cho, S.; Kim, S. The influence of optimistic bias on risk perception, tourist destination switching intention, and risk reduction behavior. J. Tour. Sci. 2018, 42, 175-190. [CrossRef]

31. Lee, C.; Lee, K. The effect of risk perception on risk reduction behavior and the moderating effect of prior knowledge of tourists. J. Tour. Leis. Res. 2017, 29, 45-63.

32. Yang, S. Risk perception and hesitation in festival setting: Focusing on COVID 19 issue involvement and issue exposure. J. Tour Stud. 2020, 32, 23-41. [CrossRef]

33. Slovic, P.; Fischhoff, B.; Lichtenstein, S. Why study risk perception? Risk Anal. 1982, 2, 83-93. [CrossRef]

34. Bauer, R.A. Consumer behavior as risk taking. In Dynamic Marketing for a Changing World; Hancock, R.S., Ed.; American Marketing Association: Chicago, IL, USA, 1960; pp. 389-398.

35. Tsaur, S.; Tzeng, G.; Wang, K. Evaluating tourist risks from fussy perspectives. Ann. Tour. Res. 1997, $24,796-812$.

36. Reisinger, Y.; Mavondo, F. Cultural differences in travel risk perception. J. Travel Tour. Mark. 2006, 20, 13-31. [CrossRef]

37. Sőnmez, S.F.; Graefe, A.R. Influence of terrorism risk on foreign tourism decisions. Ann. Tour. Res. 1998, 5, 112-144. [CrossRef]

38. Yuksel, A.; Yuksel, F. Shopping risk perceptions: Effects on tourists' emotions, satisfaction and expressed loyalty intentions. Tour. Manag. 2007, 28, 703-713. [CrossRef]

39. Lepp, A.; Gibson, H. Tourist roles, perceived risk and international tourism. Ann. Tour. Res. 2003, 30, 606-624. [CrossRef]

40. Dolnicar, S. Understanding barriers to leisure travel-tourist fears as marketing basis. J. Vacat. Mark. 2005, 11, 197-208. [CrossRef]

41. Larsen, S.; Brun, W. I am not at risk-Typical tourists are! Social comparison of risk in tourists. Perspect. Public Health 2011, 131, 275-279. [CrossRef]

42. Kim, J.; Lee, M.; Han, H. Smart hotels and sustainable consumer behaviors: Testing the effect of perceived performance, attitude, and technology readiness on word-of-mouth. Int. J. Environ. Res. Public Health 2020, 17, 7455. [CrossRef] [PubMed]

43. Korea National Park Service. Available online: https://www.knps.or.kr/front/portal/stats/statsDtl.do?menuNo=8000627\& refId=REFM000575\&page $=1 \&$ searchAllValue $=($ accessed on 1 September 2021) .

44. Assael, H. Consumer Behavior and Marketing Action; Keat Publishing Co.: Boston, MA, USA, 1995.

45. Mitchell, V.W. Consumer perceived risk: Conceptualisations and models. Eur. J. Mark. 1999, 33, 163-195. [CrossRef]

46. Seo, S. Chinese tourist's risk reduction strategies differences based on their perceived risk of Korean food restaurants. J. Tour. Sci. 2014, 38, 249-269.

47. Fishbein, M.; Ajzen, I. Belief, Attitude, Intention, and Behavior: An introduction to Theory and Research, Reading; Addison-Wesley: Boston, MA, USA, 1975.

48. Lee, K.I.; Gould, R. Predicting congregate meal program participation: Applying the extended theory of planned behavior. Itl. J. Hosp. Manag. 2012, 31, 828-836. [CrossRef]

49. Courneya, K.S. Understanding readiness for regular physical activity in older individuals: An application of the theory of planned behavior. Health Psychol. 1995, 14, 80-87. [CrossRef] [PubMed]

50. Quine, L.; Rutter, D.R.; Arnold, L. Comparing the Theory of Planned Behaviour and the Health Belief Model: The Example of Safety Helmet Use Among Schoolboy Cyclists. In Understanding and Changing Health Behaviour; Psychology Press: London, UK, 2013; pp. 89-114.

51. Lee, J.; Kim, H.N. Factors affecting high school and college students' intention to produce UCC. Korean J. Jour. Com. Stud. 2008, 52, 399-419.

52. Park, H.; Hahn, D. The integrated model to explain the behaviors of purchasing luxury brands of Korean women. Korean J. Consum. Advert. Psychol. 2006, 7, 195-226.

53. Tonglet, M.; Philips, P.; Read, A. Using the theory of planned behaviour to investigate the determinants of recycling behaviour: A case study from Brixworth, UK. Resour. Conserv. Recycl. 2004, 41, 191-214. [CrossRef]

54. Armitage, C.J.; Conner, M. Efficacy of the theory of planned behaviour: A meta-analytic review. Br. J. Soc. Psychol. 2001, 40, 471-499. [CrossRef]

55. Chi, X.; Han, H. Exploring slow city attributes in mainland China: Tourist perceptions and behavioral intentions toward Chinese Cittaslow. J. Travel Tour. Mark. 2020, 37, 361-379. [CrossRef]

56. Moon, H.; Yoon, H.; Han, H. The effect of airport atmospherics on satisfaction and behavioral intentions: Testing the moderating role of perceived safety. J. Travel Tour. Mark. 2017, 34, 749-763. [CrossRef]

57. Rivis, A.; Sheeran, P. Social influences and the theory of planned behavior: Evidence for direct relationship between prototypes and young people's exercise behavior. Psychol. Health 2003, 18, 567-583. [CrossRef]

58. Kim, Y.J. The Comparison Verification of Model for the Exercise Adherence's Validation. Ph.D. Thesis, Department of Physical Education, Chung-Ang University, Seoul, Korea, 30 August 2001.

59. Park, Y.; Hyun, Y. Examining the mass media influence and social influence on potential visitors' intention to Cardinal Stephen Kim Sou-Hwan's memorial park: A focus on the mediating and moderating role of involvement. J. Tour. Sci. 2010, 34, 189-209.

60. Perugini, M.; Bagozzi, R.P. The role of desires and anticipated emotions in goal-directed behaviours: Broadening and deepening the theory of planned behaviour. Br. J. Soc. Psychol. 2001, 40, 79-98. [CrossRef]

61. Bagozzi, R.P.; Warshaw, P.R. An examination of the etiology of the attitude-behavior relation for goal-directed behaviors. Multivar. Behav. Res. 1992, 27, 601-634. [CrossRef] [PubMed]

62. Han, H.; Kim, Y. Intention to pay conventional-hotel prices at a green hotel: A modification of the theory of planned behavior. J. Sustain. Tour. 2010, 18, 997-1014. [CrossRef] 
63. Hsu, C.H.C.; Huang, S. An extension of the theory of planned behavior model for tourists. J. Hosp. Tour. Res. 2012, 36, 390-417. [CrossRef]

64. Lam, T.; Hsu, C.H.C. Theory of planned behavior, potential travelers from China. J. Hosp. Tour. Res. 2004, 28, 463-482. [CrossRef]

65. Lam, T.; Hsu, C.H.C. Predicting behavioral intention of choosing a travel destination. Tour. Manag. 2006, 27, 589-599. [CrossRef]

66. Lee, M.J.; Back, K.J. Association members' meeting participation behaviors. J. Travel Tour. Mark. 2012, 22, 15-33. [CrossRef]

67. Quintal, V.; Lee, J.; Soutar, G. Risk, uncertainty and the theory of planned behavior: A tourism example. Tour. Manag. 2010, 31, 797-805. [CrossRef]

68. Sparks, B.; Pan, G.W. Chinese outbound tourists: Understanding their attitudes, constraints and use of information sources. Tour. Manag. 2009, 30, 483-494. [CrossRef]

69. Yoon, S.; Oh, S.; Yoon, S. A study for the effect relationship about overseas trip intention of local by using theory of planned behavior(TPB): Focusing on the additional role of prior knowledge and perceived risk. Korean J. Hotel Adm. 2010, 19 , $289-307$.

70. Lee, H.; Kim, N. The impact of fine particular matter risk perception on the outdoor behavior of recreationists: An application of the extended theory of planned behavior. J. Tour. Sci. 2017, 41, 27-44.

71. Sheth, J.N.; Venkatesan, M. Risk-reduction processes in repetitive consumer behavior. J. Mark. Res. 1968, 5, 307-310. [CrossRef]

72. Kim, H.K.; Kim, Y. Protective behaviors against particulate air pollution: Self-construal, risk perception, and direct experience in the theory of planned behavior. Environ. Commun. 2021, 15, 1092-1108. [CrossRef]

73. Lee, Y. Relationships among environmental attitudes, risk perceptions, and coping behavior: A case study of four environmentally sensitive townships in Yunlin county, Taiwan. Sustainability 2018, 10, 2663. [CrossRef]

74. Lopez-Vazquez, E.; Marvan, M.L. Risk perception, stress and coping strategies in two catastrophe risk situations. Soc. Behav. Personal. Int. J. 2003, 31, 61-70. [CrossRef]

75. Manning, R.E. Studies in Outdoor Recreation; Oregon State University Press: Corvallis, OR, USA, $1986 ;$ p. 49.

76. Kim, S.; Hong, J. Recreational demand and crowdedness perception: A test for user displacement hypothesis. Korean J. Tour. Res. 1998, 12, 181-195.

77. Han, H.; Hong, K. A study on social carrying capacity and coping behavior in the regional festival—A case of Puchon international student animation festival(PISAF 2004)-. Int. J. Tour. Hosp. Res. 2006, 20, 121-137.

78. Kim, S.; Jung, H.; Kim, K. A study on the relationship between perceived crowding, satisfaction, coping behavior, and behavioral intention in theme park visitors: Focusing on the Chinese tourists visiting "E" theme park. Int. J. Tour. Hosp. Res. 2015, $29,65-76$.

79. Shaw, J.M.; Brown, R.F.; Dunn, S.M. A qualitative study of stress and coping responses in doctors breaking bad news. Patient Educ. Couns. 2013, 91, 243-248. [CrossRef]

80. Shindler, B.; Shelby, B. Product shift in recreation setting: Findings and implications from panel research. Leis. Sci. 1995, 17, 91-104. [CrossRef]

81. Adam, I. Backpackers' risk perceptions and risk reduction strategies in Ghana. Tour. Manag. 2015, 49, 99-108. [CrossRef]

82. Johnson, T. Generic consumer risk-reduction strategies in wine-related lifestyle segments of the Australian wine market. Int. J. Wine Mark. 2004, 16, 5-35. [CrossRef]

83. Quan, W.; Al-Ansi, A.; Han, H. Spatial and human crowdedness, time pressure, and Chinese traveler word-of-mouth behaviors for Korean restaurants. Int. J. Hosp. Manag. 2021, 94, 1-10. [CrossRef]

84. Chu, K.K.; Li, C.H. A study of the effect of risk reduction strategies on purchase intentions in online shopping. Int. J. Electron. Bus. Manag. 2008, 6, 213-226.

85. Si, H.; Shen, L.; Liu, W.; Wu, G. Uncovering people's mask-saving intentions and behaviors in the post-COVID-19 period: Evidence from China. Sustain. Cities Soc. 2021, 65, 102626. [CrossRef] [PubMed]

86. Shi, G.; Zhong, X.; He, W.; Liu, H.; Liu, X.; Ma, M. Factors influencing protective behavior in the post-COVID-19 period in China: A cross-sectional study. Environ. Health Prev. Med. 2021, 26, 1-12. [CrossRef]

87. Mitchell, V.W.; Davies, F.; Moutinho, L.; Vassos, V. Using neural networks to understand service risk in the holiday product. J. Bus. Res. 1999, 46, 167-180. [CrossRef]

88. Lim, M.; Lim, M.; Lee, Y. From tourism event the perceived risk affects in attitudes and visit intentions. Crisis 2010, 6, 132-143.

89. Lee, H. Analysis of causal structure on the formation and influence of crowding perception for winter tourists at a beach resort. $J$. Tour. Sci. 2000, 23, 47-67.

90. Manning, R.E. Studies in Outdoor Recreation: Search and Research for Satisfaction; Oregon State University Press: Corvallis, OR, USA, 1999.

91. Ajzen, I. Perceived behavioral control, self-efficacy, locus of control, and the theory of planned behavior. J. Appl. Soc. Psychol. 2002, 32, 1-20. [CrossRef]

92. Doll, J.; Ajzen, I. Accessibility and stability of predictors in the theory of planned behavior. J. Personal. Soc. Psychol. 1992, 63, 754-765. [CrossRef]

93. Hu, L.T.; Bentler, P.M. Cutoff criteria for fit indexes in covariance structure analysis: Conventional criteria versus new alternatives. Struct. Equ. Modeling A Multidiscip. J. 1999, 6, 1-55. [CrossRef]

94. Tabachnick, B.G.; Fidell, L.S. Multivariate Regression. Using Multivariate Statistics, 5th ed.; Pearson Education: Boston, MA, USA, 2007; pp. 117-159.

95. Kline, R.B. Principles and Practice of Structural Equation Modeling, 2nd ed.; Guilford: New York, NY, USA, 2005.

96. Bowen, N.K.; Guo, S. Structural Equation Modeling; Oxford University Press: Oxford, UK, 2011.

97. Hoyle, R.H. Structural Equation Modeling: Concepts, Issues, and Applications; Sage: New York, NY, USA, 1995. 
98. Dzewaltowski, D.A.; Noble, J.M.; Shaw, J.M. Physical activity participation: Social cognitive theory versus the theories of reasoned action and planned behavior. J. Sport Exerc. Psychol. 1990, 12, 388-405. [CrossRef] [PubMed]

99. Gatch, C.L.; Kendzierski, D. Predicting exercise intentions: The theory of planned behavior. Res. Q. Exerc. Sport 1990, 61, 100-102. [CrossRef]

100. Seong, B. An analysis on the factors affecting the culture-into-life activities participation intention by adopting the theory of planned behavior: A case of the citizens of Jecheon. J. Reg. Pol. 2019, 30, 43-62.

101. Dholakia, U.M.; Bagozzi, R.P.; Pearo, L.K. A social influence model of consumer participation in network-and small-group-based virtual communities. Int. J. Res. Mark. 2004, 21, 241-263. [CrossRef]

102. Hogg, M.A.; Reid, S.A. Social identity, self-categorization, and the communication of group norms. Commun. Theory 2006, 16, 7-30. [CrossRef]

103. Mayo, E.J.; Jarvis, L.P. The Psychology of Leisure Travel: Effective Marketing and Selling of Travel Services; CBI Publishing Company: Boston, MA, USA, 1982.

104. Larsen, S.; Brun, W.; Øgaard, T.; Selstad, L. Subjective food-risk judgements in tourists. Tour. Manag. 2007, 28, 1555-1559. [CrossRef]

105. Taylor, S.E.; Brown, J.D. Illusion and well-being: A social psychological perspective on mental health. Psychol. Bull. 1988, 103, 193-210. [CrossRef] [PubMed]

106. Fan, X.; Thompson, B.; Wang, L. Effects of sample size, estimation methods, and model specification on structural equation modeling fit indexes. Struct. Equ. Modeling Multidiscip. J. 1999, 6, 56-83. [CrossRef]

107. Reisinger, Y.; Turner, L. Structural equation modeling with Lisrel: Application in tourism. Tour. Manag. 1999, 20, 71-88. [CrossRef]

108. Sideridis, G.D.; Jaffari, F. An R function to correct fit indices and omnibus tests in confirmatory factor analysis. Meas. Eval. Couns. Dev. 2021, 1-27. [CrossRef]

109. Rodriguez, A.; Reise, S.P.; Haviland, M.G. Evaluating bifactor models: Calculating and interpreting statistical indices. Psychol. Methods 2016, 21, 137. [CrossRef] [PubMed]

110. Padgett, B.C.; Kim, H.; Goh, B.K.; Huffman, L. The usefulness of the theory of planned behavior: Understanding U.S. fast-food consumption of generation Y Chinese consumers. J. Foodserv. Bus. Res. 2013, 16, 486-505. [CrossRef]

111. Sa, H.J.; Lee, W.S.; Lee, B.G. Corona blue and leisure activities: Focusing on Korean case. J. Internet Comput. Serv. 2021, $22,109-121$.

112. Lopes, H.S.; Remoaldo, P.C.; Ribeiro, V.; Martín-Vide, J. Effects of the COVID-19 pandemic on tourist risk perceptions-The case study of Porto. Sustainability 2021, 13, 6399. [CrossRef] 